\title{
EKSISTENSI WAKAF DENGAN UANG DALAM SISTEM HUKUM INDONESIA
}

\author{
Fatahullah \\ Fakultas Hukum Unversitas Mataram \\ Lombok, NTB, Indonesia \\ Email: ullaw84@yahoo.co.id
}

\begin{abstract}
Abstrak
Wakaf termasuk kategori amal jariyah yang pahalanya akan mengalir terus kepada si wakif atau orang yang mewakafkan. Selama ini objek wakaf diidentikan dengan benda yang tidak bergerak berupa tanah, bangunan, pohon-pohonan dan sumber air. Sedangkan wakaf uang atau surat berharga lain dianggap tidak sah. Wakaf dengan uang merupakan suatu instrument wakaf baru di Indonesia walaupun bukan suatu yang baru di dunia Muslim. Wakaf dengan uang menimbulkan pro dan kontra disebabkan karena wujud/fisik uang itu sendiri akan hilang ketika dimanfaatkan atau digunakan. Hal ini akan bertentangan dengan arti wakaf itu sendiri yaitu menahan pokoknya dan menyalurkan hasilnya. Sehingga untuk menahan pokok tersebut haruslah berupa benda atau barang yang tahan lama. Di Indonesia saat ini wakaf dengan uang telah diatur dalam Undang-Undang Nomor 41 tahun 2004 tentang wakaf dan Peraturan Pemerintah Nomor 42 tahun 2006 yang diganti dengan Peraturan Pemerintah No. 25 tahun 2008. Sebelumnya Wakaf uang dibolehkan dalam Fatwa Majelis Ulama Indonesia pada tangga 11 Mei 2002. Pengaturan secara yuridis formal tersebut bukan hanya menyangkut konsepsi terhadap wakaf dan wakaf uang tetapi juga menyangkut mekanisme administratif terhadap wakaf uang Pendayagunaan wakaf uang dilakukan oleh lembaga keuangan syariah yakni Perbankan Syariah dengan menggunakan system bagi hasil melalui akad Mudharabah. Hasil yang diperoleh dari akad tersebut akan digunakan sesuai ikrar wakaf yang dilakukan oleh wakif dengan memperhatikan prinsipprinsip syariah.
\end{abstract}

\section{Kata Kunci: Wakaf Uang; System Hukum Indonesia .}

\section{A. PENDAHULUAN}

Dogma agama Islam mengajarkan bahwa Semua bentuk aktivitas manusia hendaklah ditujukan sebagai bentuk ibadah kepada Allah. Tujuan penciptaan manusia adalah untuk menyembah Allah sebagaimana dijelaskan dalam Qur'an Surat Al-Dzariyaat ayat 56. Ada banyak bentuk ibadah dalam Islam baik dalam ibadah hablumminallah maupun ibadah hablumminnas. Salah satu ibadah yang memiliki dimensi langsung kepada Allah SWT. sekaligus sekaligus bernilai sosial adalah wakaf. Wakaf di zaman Islam ditandai dengan pembangunan masjid Quba, yaitu masjid yang dibangun atas dasar takwa sejak dari pertama Nabi Muhamad SAW melakukan hijrah ke Madinah, Kemudian dilanjutkan dengan pembangunan
Masjid al-Nabawi yang dibangun di atas tanah anak yatim dari Bani al-Najjar setelah dibeli oleh Rasulullah.

Wakaf merupakan salah satu bentuk ibadah yang sangat dianjurkan dalam agama Islam selain zakat, infaq dan shadaqah. Pahala wakaf akan mengalir bagi orang yang berwakaf (wakif) walaupun yang bersangkutan telah meninggal dunia. Sebagaimana dinyatakan dalam sebuah hadist yang diriwayatkan oleh Imam Muslim

"Diceritakan oleh Yahya Ibnu Ayyub dan Qutaibah (yaitu Ibnu Said dan Ibnu Hajar, mereka berkata diceritakan Ismail bin Ja'far dari Ala' dari bapaknya dari Abi Hurairah: Sesungguhnya Rasulullah SAW bersabda (Apabila anak Adam (manusia) meninggal dunia maka putuslah amalnya, 
kecuali tiga perkara; shodaqah jariyah (wakaf), ilmu yang bermanfaat dan anak sholeh yang selalu mendoakan kedua orang tuanya".

Kata jariyah diatas menunjukan pada sesuatu (derma) yang selalu mengalir secara terus menerus walaupun pemberinya telah meninggal dunia. Imam Nawawi dalam kitabnya, Syarh Shahih Muslim menjelaskan, yang dimaksud dengan shadaqah jariyah adalah wakaf ${ }^{1}$. Wakaf merupkan sedekah individu yang pokok (asalnya) tidak boleh habis, sehingga akan ada keberlanjutan dalam memanfaatkan harta wakaf tersebut. Selain sebagai sarana ibadah sebagai bentuk hubungan manusia kepada Allah, wakaf juga merupakan bentuk hubungan dengan manusia. Oleh sebab itu kedudukan wakaf sangat penting dalam menjaga hubungan kepada Allah dan juga manusia.

Menurut Ter Haar wakaf merupakan lembaga hukum Islam yang telah diterima (gerecipreed) dihampir semua wilayah Nusantara yang dalam istilah Belanda Vrome Stiching. Artinya, keseluruhan konsepsi tentang wakaf sudah menjadi bagian yang tak terpisahkan dengan adat istiadat masyarakat Indonesia, dan sejak dulu diatur dalam hukum adat yang sifatnya tidak tertulis dengan mengambil sumber dari hukum Islam ${ }^{2}$.

Jumlah penduduk Indonesia yang mayoritas muslim merupakan satu potensi dalam berkembangnya lembaga wakaf di masyarakat. Akan tetapi selama ini konsepsi wakaf hanya pada tataran barang tidak bergerak saja seperti tanah dan bangunan, sehingga wakaf menjadi stagnan. Akan tetapi akhir-akhir ini di Indonesia mulai berkembang wakaf harta bergerak seperti uang dan surat berharga, sehingga penggunaannya dapat dilakukan secara fleksibel untuk memberikan manfaat yang semakin besar bagi kesejahteraan masyarakat. Sedangkan dari sisi kuantitas akan semakin masyarakat

\footnotetext{
1 http://wakafproduktif.org/hikmah-wakaf-sebagai-ibadah-sosial/ Diakses pada tanggal 11 maret 2013

${ }^{2}$ Muhammad Daud Ali.(1988). Sistem Ekonomi Islam, Zakat Dan Wakaf. Jakarta: Universitas Indonesia,
} hlm. 122. yang dapat mewakafkan sebagian hartanya karena tidak harus menunggu memiliki tanah atau bangunan yang cenderung dari waktu ke waktu terkadang harganya tidak dapat dijangkau oleh sebagian masyarakat.

Ketua Umum Ikatan Ahli Ekonomi Islam Indonesia (IAEI), Mustafa Edwin Nasution, mengungkapkan, potensi wakaf uang di Indonesia sangat besar, bisa mencapai $\mathrm{Rp}$ 20 triliun per tahunnya. ${ }^{3}$ Wakil ketua Badan Wakaf Indonesia (BWI) itu mencontohkan, jika 10 juta umat Muslim di Indonesia mewakafkan uangnya mulai dari Rp 1.000 sampai Rp. 100 ribu per bulan, minimal dana wakaf uang yang akan terkumpul selama setahun bisa mencapai Rp 2,5 triliun. Selanjutnya menurut Mustafa Edwin Nasution jika sekitar 20 juta umat Islam di Tanah Air mewakafkan hartanya sekitar Rp 1 juta per tahun, potensi wakaf uang bisa mencapai $\mathrm{Rp}$ 20 triliun. $^{4}$

Dari uraian tersebut diatas, maka permasalahannya adalah pertama apakah wakaf uang atau wakaf dengan uang tersebut tidak bertentangan dengan hukum Islam yang selama ini dipahami oleh masyarakat bahwa objek wakaf harus kekal atau tidak habis dipakai sesuai dengan pengertian wakaf itu sendiri yakni menahan pokoknya sedangkan uang tunai akan habis ketika dibelanjakan; kedua Bagaimana sistem hukum Indonesia mengatur wakaf dengan uang tersebut; dan ketiga Bagaimana pengaturan pendayagunaan uang wakaf sehingga tidak bertentangan dengan hukum Islam.

\section{B. PEMBAHASAN}

\section{Konsepsi Wakaf dengan Uang menurut Hukum Islam}

Islam mengajarkan kepada umatnya bahwa segala yang ada dilangit dan dibumi ini adalah milik Allah SWT termasuk didalamnya adalah harta, dan manusia hanya diserahkan

\footnotetext{
${ }^{3} \mathrm{http}$ ://www.republika.co.id/berita/dunia-islam/islam-nusantara/12/07/22/m7jb3w-potensi-wakaf-uang-sungguh-luar-biasa. diakses tanggal 3 November 2014

${ }^{4}$ Ibid.
} 
tugas untuk mengelola dan memanfaatkan sementara waktu saja. Hal ini sebagaimana firman Allah SWT dalam surah Al-Baqarah ayat 29:

"dialah Allah yang menjadikan segala yang ada dibumi untuk kamu dan dia berkehendak (menciptakan) langit, lalu dijadikannya tujuh lapis langit, dan dia maha mengetahui segala sesuatu”.

Selanjutnya dalam QS. Al-Baqarah ayat 284 dikatakan:

"Kepunyaan Allahlah segala apa yang ada dilangit dan dibumi..."

Sedangkan dalam Surah An-Nur ayat 33:

“...dan berikanlah kepada mereka sebagian dari harta Allah yang dikaruniakanNya kepadamu...",

Harta bukanlah sebagai objek kesenangsenangan dunia semata sebagaimana konsep dunia materialis saat ini, tetapi harta merupakan bekal ibadah berkaitan dengan cara pemanfaatanya baik untuk keperluan kehidupan pribadi maupun ibadah sosial dalam bentuk wakaf, infak, zakat dan shadaqah kesemuanya tersebut dihari akhir akan dimintakan pertanggungjawabannya.

Ahmad al-Syarbasi menyebutkan ada lima syarat pemilikan harta yang dibenarkan oleh syariat yakni: ${ }^{5}$

a. Diperolehmelaluicarayangdibenarkanoleh syara';

b. Barang tersebut halal dan baik;

c. Dimanfaatkan tidak dengan cara yang berlebihan dan menyimpang;

d. Menunaikan hak Allah atas barang tersebut berupa zakat dan perbuatan baik lainnya, juga masyarakat lainnya yang memberikan manfaat bagi kemaslahatan umum;

e. Tidak dimanfaatkan dengan tujuan yang memberikan mudharat kepada pihak lain, baik perorangan, kelompok dan umat.

Doktrin agama Islam bagi setiap muslim bahwasannya belum sempurna iman sesorang muslim sebelum dia mendermakan sebagian dari harta yang dimilikinya dijalan Allah,

${ }^{5}$ Abdul Halim Barkatullah dan Teguh Prasetio.(2006). Hukum Islam. Yogyakarta: Pustaka Pelajar. hlm. 223-224 sebagaimana firman-Nya dalam QS. Ali Imran ayat 92:

"Kamu sekali-kali tidak sampai kepada kebajikan (yang sempurna), sebelum kamu menafkankan sebagian harta yang kamu cintai. Dan apa saja yang kamu nafkahkan maka sesungguhnya Allah mengetahuinya".

Menurut ulama tafsir yang dimaksud dengan kebaikan pada ayat ini adalah surga atau kebaikan dari Allah SWT secara umum. Sedangkan Prof. Dr. Hamka menjelaskan bahwasanya menyebut iman adalah mudah, tetapi mencapai hasil iman yang mulia adalah suatu ujian hati yang berat. Orang belum akan mencapai kebaikan (birr) atau idupnya yang baik, atau jiwa yang baik, kalau dia belum sanggup mendermakan barang yang paling dicintainya. Dalam surat al-baqarah juga diterangkan bahwasanya (birr) bukan semata-mata buat menghadapkan muka ke timur ataupun ke barat, tetapi antara syaratsyarat untuk menjadi orang baik ialah sudi mengeluarkan hartabenda padahal kita cinta kepadanya. Jangan sampai memberikan derma apapun kepada orang lain, yang jika misalnya engkau sendiri yang menerimanya, engkau akan memicingkan mata, hanya karena terpaksa saja. Sekarang dijelaskan bahwa kebaikan tidak akan tercapai kalau belum sanggup mendermakan apa saja yang paling dicintai. Kalau martabat ini telah tercapai, inilah baru boleh diakui bahwa dia adalah seorang baik yang telah mencapai kebaikan. ${ }^{6}$

Dalam Islam, sedekah di bagi menjadi dua jenis, yaitu sedekah wajib dan sedekah sunnah. Diantara sedekah yang sunnah adalah wakaf, hibah dan wasiat. Ketiga jenis sedekah tersebut memiliki pengertian dan aturan masingmasing. Apabila seseorang menyedekahkan suatu barang untuk dimanfaatkan saja sementara barangnya itu tetap ada, maka perbuatan tersebut disebut dengan wakaf. Sedangkan apabila seseorang mendermakan hartanya kepada orang lain dengan perintah

\footnotetext{
${ }^{6}$ Hamka. (1987). Tafsir Al-Azhar. Jakarta: Cet.1 Jilid IV,
} Pustaka Panjimas. hlm. 6. 
pelaksanaannya dilaksanakan setelah dia meninggal dunia, maka perbuatan tersebut disebut dengan wasiat. Wakaf merupakan salah satu tuntunan ajaran Agama Islam yang menyangkut kehidupan bermasyarakat dalam rangka ibadah ijtima'iyah (ibadah sosial). Karena wakaf adalah ibadah, maka tujuan utamanya adalah pengabdian kepada Allah SWT dan ikhlas mencari ridha-Nya. ${ }^{7}$

Wakaf secara ringkas didefinisikan dengan: "Menahan kapital dan membelanjakan hasilnya". Definisi ini berasal dari hadis Nabi Riwayat Bukhari dan Muslim bahwa ketika Umar bin Khattab bercerita kepada Nabi Muhammad mengenai sebidang tanah miliknya di Khaibar, lalu Nabi bersabda: "Jika engkau mau, tahan pokok (kapital)nya dan sedekahkan hasilnya”. Anjuran Nabi ini meskipun lebih sebagai penjelasan atas pernyataan Alqur'an yang mendorong sangat kuat untuk melakukan sedekah sebagai amal shaleh, tetapi juga terkait dengan lembaga yang pernah berlaku pada suku pra Islam yang disebut hima. Yaitu sebidang lahan yang disisihkan oleh suatu suku sebagai harta masyarakat untuk menggembalakan ternak dan sebagainya, yang tidak bisa diklaim baik oleh individu maupun keluarga manapun. Dalam hal ini, wakaf berawal dari praktik hima sebagai faktor produksi bersama yang tujuannya adalah untuk perwujudan keadilan ekonomi. Praktik wakaf juga didasarkan pada hadis Riwayat Muslim, dimana wakaf merupakan sebuah upaya pengabdian amal tentu saja bersifat relatif kendati pelakunya sudah meninggal dunia, lewat pemanfaatan benda yang diwakafkan oleh publik untuk kemaslahatannya. Dengan begitu, diharapkan pahalanya tetap mengalir kepada para pewakaf. Dalam hadis tersebut, sebagai tindakan yang tidak terputus pahalanya, walaupun pelakunya sudah meninggal dunia, sedekah jariyah (wakaf) sebanding dengan ilmu yang bermanfaat dan anak saleh yang mendoakan.

${ }^{7}$ Abdul Ghofur Anshori.(2005). Hukum dan Praktek Perwakafan di Indonesia. Yogyakarta: Pilar Media. hlm. 1
Dari beberapa ayat dan hadist yang dijadikan sebagai dasar pelaksanaan wakaf menurut Hukum Islam tidak ada yang menyebutkan istilah wakaf akan tetapi ulama bersepakat bahwa ayat-ayat dan hadist tentang sedekah dapat dijadikan sebagai sandaran pelaksanaan wakaf yang sudah dipraktekkan pada masa sahabat Rasulullah. Senada dengan tersebut Sayyid Alwi alMaliki ketika berbicara tentang Istishhab, memformulasikan kaidah ushul fiqh "al-ashl fial-madharr al-tahrim wa al-manafi'al-hill" (pada prinsipnya kerusakan adalah haram dan kemanfaatan adalah halal). Dari kaidah ini dapat menemukan etika Hukum Islam, yaitu kemanfaatan pasti boleh dan kerusakan pasti haram ${ }^{8}$.

Monzer Qahf mengemukakan bahwa al-Zarqa mengemukakan setiap apa yang berkaitan dengan wakaf adalah persoalan ijtihadi dan ijma' ulama ${ }^{9}$, sehingga persoalan wakaf terbuka adanya penafsiran-penafsiran baru terhadap ayat-ayat dan hadist dengan pendekatan yang konstekstual. Dengan demikian, wakaf dalam al-Qur'an dan Hadist bersifat zhanni al-dlalalah yang membuka interpretasi kepada setiap muslim untuk kemaslahatan umat. Oleh karena itu ulama hanya membuatkan kriteria atau syarat barang atau benda yang dapat dijadikan sebagai objek wakaf.

Muhammad Mushthafa Syalabi menjelaskan bahwa syarat-syarat objek wakaf ada empat: Pertama, harta tersebut harus mutaqawwim (memungkinkan untuk dijaga atau dipelihara dan memungkinkan untuk dimanfaatkan dengan cara tertentu); Kedua, harta yang diwakafkan dapat diketahui secara sempurna oleh wakif dan pengelola (penerima) wakaf ketika wakaf diikrarkan; Ketiga, benda yang diwakafkan adalah milik wakif secara sempurna dan dapat dipindahtangankan ketika benda tersebut diikrarkan untuk wakaf; Keempat, benda

\footnotetext{
${ }^{8}$ Nawawi Thabrani, (2009), Wakaf Uang Dalam Perspektif Ushul Figh, Istinbath, IAIN Mataram, Volume 7 Nomor 2 , hlm. 258

${ }^{9}$ Ibid., hlm. 259
} 
yang diwakafkan dapat dipisahkan secara tegas tanpa terikat dengan yang lain. ${ }^{10}$

Barang atau benda yang dapat dijadikan sebagai objek wakafpun masih ada perbedaan pendapat disebabkan karena tidak ada ayat al-Qur'an yang menyebutkannya secara langsung. Akan tetapi objek wakaf (mauquf) jumhur ulama mengatakan bahwa objek wakaf adalah harta benda (al-ain) yang berwujud dan tahan lama dengan tujuan agar dapat dimanfaatkan secara terus menerus sehingga pahala terhadap wakif akan mengalir terus-menerus. Contoh barang dapat dijadikan sebagai objek wakaf adalah tanah, bangunan, pohon-pohonan, mata air dan lain-lain. Sedangkan wakaf dalam bentuk uang/tunai masih terjadi perbedaan pendapat diantara para ulama.

Wahbah Az-Zuhaili juga mengungkapkan bahwa mazhab Hanafi membolehkan wakaf tunai sebagai pengecualian, atas dasar Istihsan bi al-'Urfi, karena sudah banyak dilakukan masyarakat. Cara melakukan wakaf tunai (mewakafkan uang), menurut mazhab Hanafi, ialah dengan menjadikannya modal usaha dengan cara mudharabah. Sedang keuntungannya disedekahkan kepada pihak wakaf. ${ }^{11}$

Menurut As'ad (2006), di kalangan Ulama klasik, wakaf uang menjadi persoalan khilafiyyah (perbedaan pendapat). Hal tersebut bermula ketika tradisi yang lazim bahwa masyarakat mewakafkan hartanya yang hanya berkisar pada harta tetap (fixed asset). Berdasarkan tradisi tersebut, maka sebagian Ulama merasa aneh saat mendengar fatwa yang dikeluarkan oleh sahabat Abu Hanifah yang bernama Muhammad Abdullah Al-Anshaari yang menyatakan bolehnya berwakaf dalam bentuk uang kontan, seperti dinar atau dirham, atau dalam bentuk komoditi yang ditimbang. Hal yang membuat mereka merasa aneh adalah, berubahnya

${ }^{10}$ Miftahul Huda. (2012). Arah Pembaruan Hukum Wakaf Indonesia. Ulumuna Jurnal Studi Keislaman, Volume 16 Nomor 1. hlm. 127-128.

${ }_{11}$ Kementerian Agama RI Direktorat Jenderal Bimbingan Masyarakat Islam Direktorat Pemberdayaan Wakaf. (2013). Buku Panduan Pengelolaan Wakaf Tunai. hlm. 2 fungsi utama dari uang tersebut sebagai alat tukar menjadi alat sewa wakaf. Al-Anshari menjawab: "Kita investasikan dana tersebut dengan cara mudharabah, dan keuntungannya disedekahkan. Kita jual makanan tersebut, harganya kita putar dengan usaha mudharabah lalu hasilnya kita sedekahkan". ${ }^{12}$

Sedangkan Ibn Abidin mengemukakan bahwa wakaf tunai yang dikatakan merupakan kebiasaan yang berlaku di masyarakat adalah kebiasaan yang berlaku di wilayah Romawi, sedangkan di negeri lain wakaf tunai bukan merupakan kebiasaan. Karena itu Ibn Abidin berpandangan bahwa wakaf tunai tidak boleh atau tidak sah. Yang juga berpandangan bahwa wakaf tunai tidak boleh adalah mazhab Syafi'i. Menurut Al-Bakri, mazhab Syafi'i tidak membolehkan wakaf tunai, karena dirham dan dinar (baca:uang) akan lenyap ketika dibayarkan sehingga tidak ada lagi wujudnya ${ }^{13}$.

Fanani (2011) menjelaskan, bahwa alasan ulama yang tidak membolehkan wakaf uang antara lain adalah, pertama, uang sebagai alat tukar yang habis zatnya sekali pakai. Uang hanya bisa dimanfaatkan dengan membelanjakan sehingga bendanya lenyap. Sedangkan inti ajaran wakaf adalah pada kesinambungan hasil dari modal yang tetap, tidak habis sekali pakai. Oleh karena itu, syarat harta benda wakaf adalah harta yang bersifat kekal dan tahan lama, tidak habis sekali pakai. Kedua, uang dinar dan dirham merupakan alat tukar yang digunakan untuk memudahkan transaksi jual beli, bukan untuk ditarik manfaatnya dan mempersewakan zatnya. ${ }^{14}$ Namun para ulama yang melarang wakaf uang mendapatkan bantahan dari ulama yang membolehkannya diantaranya, Imam Malik, Imam Ahmad bin Hambal, dan Ibnu Syihab Az-Zuhri (dari kalangan Syafi'iyyah). Wahbah Az-Zuhaily menyebutkan bahwa, Hanafiyyah membolehkan wakaf uang karena

\footnotetext{
${ }^{12}$ Aam S. Rusydiana\& Abrista Devi, (2017), Analisis Pengelolaan Dana Wakaf Uang Di Indonesia. Pendekatan Metode Analytic Network Process (Anp), Jurnal Al-Awqaf, Volume 10 No. 2, hlm. 117

${ }^{13}$ Kementerian Agama, Op.Cit..,hlm..3

${ }^{14}$ Aam S. Rusydiana\& Abrista Devi, Op. Cit. hlm. 118
} 
substansi uang yang dapat dijadikan sebagai modal usaha tersebut dapat bertahan lama dan banyak manfaatnya untuk kemaslahatan umat, yaitu dengan menjadikannya modal usaha dengan sistem mudharabah. ${ }^{15}$

Apabila dicermati bahwa wakaf termasuk dalam kategori sadakah jariyah yang amal/ pahalanya akan mengalir terus kepada wakif disebabkan karena penggunaan objek wakaf dapat memberikan manfaat kepada banyak orang. Berdasarkan hal tersebut maka sebenarnya wakaf dengan uang memiliki nilai manfaat yang sama atau mungkin dapat melebihi nilai manfaat objek wakaf atas benda tetap seperti tanah dan bangunan. Karena tanah dapat saja terjadi erosi dan abrasi yang menyebabkan tanah wakaf menjadi berkurang atau hilang, begitupun dengan bangunan yang nilainya dapat berkurang karena kondisi dan usia bangunan tersebut. Sedangkan wakaf uang memang secara wujud/fisik uang wakaf akan hilang seiring dengan penggunaan uang tersebut, tetapi nilai atas uang tersebut tetap akan terpelihara sesuai dengan nominal yang diikrarkan dalam wakaf.

Mengenai sifat fisik barang, hal itu bukan soal yang substantif dan prinsipil. Meski zat uangnya lenyap ketika digunakan, tapi nilainya bisa tetap terpelihara dan mungkin terus menerus mendatangkan hasil. Memang barang yang sifat fisiknya dapat bertahan lama dan mendatangkan banyak manfaat tentu lebih baik, namun jauh lebih baik dan prinsipil dari semua itu ialah keabadian manfaat dan nilai dari benda yang diwakafkan ${ }^{16}$.

Pemanfaatan wakaf uang untuk kesejahteraan masyarakat seperti misalnya misalkan program layanan kesehatan gratis bagi dhuafa, sekolah gratis bagi anak yatim, bantuan usaha bagi usaha mikro, dan lainnya. Kondisi tersebut apabila mampu direalisasikan maka akan menghasilkan manfaat sosioekonomi yang besar bagi negara. Agar kondisi tersebut dapat terjadi maka perlu adanya

\footnotetext{
${ }^{15}$ Ibid.

${ }^{16}$ Pendapat ini dirangkum dari berbagai sumber. Lihat Latif Ali Romadhoni, (2015), Studi Analisis Fatwa Majelis Ulama Indonesia Tahun 2002 Tentang Wakaf Uang, Jurnal Az Zarqa', Vol. 7, No. 1, hlm. 57
}

regulator yang bertugas membuat peraturan serta melakukan supervisi atas pengelolaan wakaf yang dilakukan oleh nazhir. Hal ini dapat dilihat dari sistem wakaf berikut:

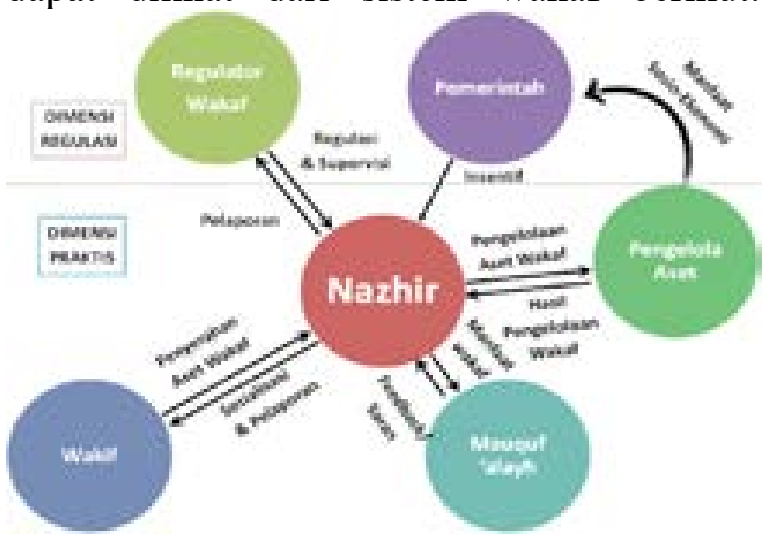

Gambar 1. Sistem Wakaf

\section{Pengaturan Wakaf Dengan Uang Menu- rut Sistem Hukum Indonesia}

Wakaf uang (cash waqf) sebenarnya bukanlah hal baru dalam hokum Islam karena beberapa ulama klasik telah membolehkan dilakukannya wakaf uang tersebut, sebut saja misalnya adalah Imam Az-Zufar pada abad ke 8 Masehi, salah satu ulama kalangan Madhzab Hanafiyyah. Beliau menyatakan bahwa, wakaf uang harus dinvestasikan melalui mudharabah dan keuntungannya dialokasikan untuk al-a'maal alkhairiyyah (bantuan sosial). Pendapat tersebut diamini juga oleh Imam Bukhari dan Ibnu Syihaab Azzuhri. Imam Bukhari menyebutkan bahwa Ibnu Syihaab Az-Zuhri membolehkan wakaf dinar dan dirham, dengan menjadikan dinar dan dirham tersebut sebagai modal usaha. Begitupun juga dengan Imam Malik, Imam Ahmad bin Hambal, dan dari kalangan Syafi'iyyah antara lain Ibnu Syihab Az-Zuhri, Abu Tsaur dari Imam al-Syafi'I tentang kebolehan wakaf dinar dan dirham (uang).

Sedangkan secara formal wakaf uang telah lama dipraktekkan oleh Dinasti Ayyubiyah di Mesir. Tahun 1178 M/572 H, dalam rangka menyejahterakan ulama dan kepentingan misi mazhab Sunni, Salahuddin Al-Ayyuby menetapkan kebijakan bahwa orang Kristen yang datang dari Iskandar untuk berdagang wajib membayar bea cukai. Uang hasil 
pembayaran bea cukai itu dikumpulkan dan diwakafkan kepada para fuqaha' (juris Islam) dan para keturunannya. Dinasti Ayyubiyah juga menjadikan harta milik negara yang berada di baitul maal sebagai modal untuk diwakafkan demi pengembangan madzhab Sunni untuk menggantikan mazhab Syi'ah yang dibawa dinasti sebelumnya, dinasti Fathimiyah. Selanjutnya Wakaf uang juga dipraktekkan oleh Dinasti Mamluk dan Turki Utsmani. Namun, wakaf uang baru berpengaruh secara signifikan pada abad ke16 Masehi yaitu pada zaman Turki Utsmani. Al-arnaut menjelaskan, pembanguan kota Istambul, tak lepas dari wakaf uang yang berkembang pesat sehingga menjadi pusat perdagangan.

Sedangkan di Indonesia yang masyarakatnya mayoritas bermazhab Syafi'i hanya memahami wakaf terhadap benda yang tidak bergerak saja. Hal ini terlihat dalam beberapa literatur-literatur yang ada selama ini. Disamping itu juga secara yuridis formal dalam Peraturan Pemerintah Nomor 28 tahun 1977 yang merupakan peraturan formal pertama yang mengatur wakaf hanya benda tidak bergerak (tanah) hak milik. Begitupun juga dengan Kompilasi Hukum Islam yang diatur dalam Instruksi Presiden Nomor 1 tahun 1991. Pada buku III bab I pasal 215 ayat (4) menyebutkan:

"Benda wakaf adalah segala benda baik

benda bergerak atau tidak bergerak yang memiliki daya tahan yang tidak hanya sekali pakai dan bernilai menurut ajaran Islam".

KHI tersebut belum mengatur tentang wakaf uang/tunai (cash waqf) karena yang dimaksud dengan benda bergerak dalam pasal 215 ayat (4) diatas adalah benda bergerak seperti kendaraan misalnya adalah mobil, motor, kapal dan lain-lain. Hal ini sejalah dengan ketentuan dalam pasal 216 dan 217 ayat (3) KHI. Pasal 216 menyebutkan: "Fungsi wakaf adalah mengekalkan manfaat benda wakaf sesuai dengan tujuan wakaf". Sedangkan pasal 217 ayat (3) menyebutkan: "benda wakaf sebagaimana dimaksud dalam pasal 215 ayat (4) harus merupakan benda milik yang bebas dari segala pembebanan, ikatan, sitaan dan sengketa".

Tonggak sejarah wakaf dengan uang di Indonesia dimulai dari keluarnya Fatwa Majelis Ulama Indonesia pada tanggal 11 Mei 2012. Ada beberapa pertimbangan dalam Fatwa MUI tersebut yakni:

a. bahwabagimayoritasumatIslam Indonesia, pengertian wakaf yang umum diketahui, antara lain adalah : yakni menahan harta yang dapat dimanfaatkan tanpa lenyap bendanya dengan cara tidak melakukan tindakan hukum terhadap benda tersebut, disalurkan pada sesuatu yang mubah (tidak haram) yang ada," (al-Ramli, Nihayah alMuhroj ila Syarh al-Minhaj, [Beirut: Dar al-Fikr, 1984], juz V, h. 357, Al Khatib al-Syarbaini, Mughni al-Muhraj, Beirut [Beirut: Dar al-Fikr, t.th],juz II, h.376); atau "Wakaf adalah perbuatan hukum seseorang ataukelompokorangataubadanhukumyang memisahkan sebagian dari benda miliknya guna kepentingan ibadat atau keperluan umum lainnya sesuai dengan ajaran Islam" dan "benda wakafadalah segala benda, baik bergerak atau tidak bergerak yang memiliki daya tahanyang tidak hanya sekalipakai dan bernilai menurut ajaran Islam" (kompilasi Hukum Islam di Indonesia, Bukuk III, Bab I, Pasal 215, (1) dan (4); sehingga atas dasar pengertian tersebut, bagi mereka bukan wakaf uang ( waqf al-nuqud, cash wakaf) adalah tidak sah.

b. bahwa wakaf uang memiliki fleksibilitas (keluwesan) dan kemaslahatan besar yang tidak dimiliki oleh benda lain;

c. bahwa oleh karena itu, Komisi Fatwa Majelis Ulama Indonesia memandang perlu menerapkan fatwa tentang hukum wakaf uanga untuk dijadikan pedoman oleh masyarakat.

Fatwa tersebut juga mengatur sebagai berikut:

1. Wakaf Uang (Cash Wakaf/Waqf al-Nuqud) adalah wakaf yang dilakukan seseorang, kelompokorang,lembagaataubadanhukum dalam bentuk uang tunai. 
2. Termasuk ke dalam pengertian uang adalah surat-surat berharga.

3. Wakaf Uang (Cash Wakaf/Waqf al-Nuqud) adalah wakaf yang dilakukan seseorang, kelompokorang,lembagaataubadanhukum dalam bentuk uang tunai.

4. Wakaf Uang hukumnya jawaz (boleh).

5. Nilai pokok Wakaf Uang harus dijamin kelestariannya, tidak boleh dijual, dihibahkan, dan atau diwariskan.

Substansi putusan fatwa tentang wakaf uang yang dimunculkan oleh MUI pada dasarnya mengambil pendapat Imam az-Zuhrī dan ulama mazhab Hanafi yang ajarannya tidak begitu familier di Indonesia. Berangkat dari adanya pendapat dari dua imam mazhab yang berbeda yang dimunculkan dalam substansi putusan tersebut, menjadikan aspek maqașid al-syari'ah yang bermuara pada mașlahah mursalah merupakan akar pertimbangan diputuskannya fatwa MUI tentang wakaf uang tersebut. Dalam fatwa tersebut, terdapat kecenderungan pendapat untuk mengakomodir kemaslahatan yang terdapat pada konsep wakaf uang berdasarkan pendapat az-Zuhri, ulama mazhab Hanafi, Maliki dan Hanbali seperti Ibnu Taymiyyah dan Ibnu Qudmah yang membolehkan wakaf uang. ${ }^{17}$

Sistem hukum wakaf yang sudah melembaga dalam agama Islam, selanjutnya dijadikan sebagai bagian dalam system di Indonesia. Pengakuan institusi wakaf dalam system Indonesia dimulai dari dibuatkannya Peraturan Pemerintah No. 28 tahun 1977 tentang Perwakafan Tanah Milik yang merupakan peraturan pelaksana dari UU No. 5 tahun 1960 tentang Pokok-pokok Agraria. Selanjutnya dikeluarkannya UU No. 41 tahun 2004 tentang Wakaf dan PP No. 42 tahun 2006 yang diganti dengan PP nomor 25 tahun 2008 tentang Peraturan Pelaksana atas UU No. 41 tahun 2004. Selanjutnya ada Perturan Menteri Agama No. 4 Tahun 2009 tentang Administrasi Pendaftaran Wakaf Uang.

${ }^{17}$ Latif Ali Romadhoni, (2015), Studi Analisis Fatwa Majelis Ulama Indonesia Tahun 2002 Tentang Wakaf Uang, Jurnal Az Zarqa', Vol. 7, No. 1, hlm. 60
Salah satu perubahan mendasar pada UU wakaf adalah dibolehkannya wakaf dengan benda bergerak selain benda tidak bergerak sebagaimana dipahami selama ini (pasal 16 UU wakaf). Pada pasal 16 ayat (3) mengatur objek wakaf benda bergerak yang tidak habis dikonsumsi yakni:

a. Uang;

b. Logam mulia;

c. Surat berharga;

d. Kendaraan;

e. Hak atas kekayaan intelektual;

f. Hak sewa; dan

g. Bendabergeraklainsesuaidenganketentuan syariah dan peraturan perundang-undangan yang berlaku.

Pasal 16 di atas menunjukkan bahwa dari sisi objek wakaf Indonesia telah mengadopsi semangat objek wakaf pada fikih klasik yang dipadukan dengan kebutuhan zaman. Objek wakaf pada fikih klasik, seperti pendapat Abu Hanifah, umumnya wakaf masih dikaitkan dengan barang-barang yang tidak bergerak, seperti tanah dan bangunan. Pendapat seperti ini berlaku sebelum ada Undang-Undang Nomor 41 tahun 2004 tentang wakaf, sebagaimana tertuang dalam Instruksi Presiden Nomor 1 tahun 1991 tentang Kompilasi Hukum Islam. Undangundang tentang wakaf ini memberikan keleluasaan bagi umat Islam untuk turut serta dalam program wakaf sehingga tidak perlu lagi menunggu kaya terlebih dahulu. Ini merupakan terobosan baru yang dapat memberikan peluang bagi peningkatan kesejahteraan umat Islam.

Lebih lanjut untuk memperjelas pasal 16 UU wakaf tersebut diberikan elaborasinya dalam Peraturan Pemerintah nomor 42 tahun 2006 tentang Peraturan Pelaksana UU No. 41 tahun 2004. Pada pasal 15 PP ini dijelaskan tentang jenis harta benda wakaf yang meliputi: a) Benda bergerak; b) Benda bergerak selain uang; dan c) Benda bergerak berupa uang. Di sini ada perbedaan penyebutan dengan UU, yang hanya mengklasifikasikan benda wakaf menjadi bergerak dan tidak bergerak. Namun PP ini menyebut lebih rinci dari 
benda bergerak berupa uang dan selain uang. Pembedaan ini semata-mata karena konsekuensi dari benda bergerak berupa uang dan selain uang tidaklah sama sebagaimana tercermin dalam pasal-pasal selanjutnya. Benda tidak bergerak meliputi (pasal 16):

a. Hak atas tanah sesuai dengan ketentuan peraturan perudang-undanganyangberlaku baik yang sudah maupun yang belum terdaftar;

b. Bangunanataubagianbangunanyangberdiri di atas tanah sebagaimana dimaksud pada huruf a;

c. Tanaman dan benda lain yang berkaitan dengan tanah;

d. Hak milik atas satuan rumah susun sesuai dengan ketentuan peraturan perundangundangan;

e. Benda tidak bergerak lain sesuai dengan ketentuan syariah dan peraturan perundangundangan.

Benda bergerak selain uang dijelaskan dalam pasal 19, 20, dan 21. Dalam pasal 19 disebutkan bahwa:

(1)Benda digolongkan sebagai benda bergerak karena sifatnya yang dapat berpindah atau dipindahkan atau karena ketetapan undangundang

(2)Benda bergerak terbagi dalam benda bergerak yang dapat dihabiskan dan yang tidak dapat dihabiskan karena pemakaian.

(3)Benda bergerak yang dapat dihabiskan karena pemakaian tidak dapat diwakafkan, kecuali air dan bahan bakar minyak yang persediaannya berkelanjutan.

(4)Benda bergerak yang tidak dapat dihabiskan karenapemakaiandapatdiwakafkandengan memperhatikan ketentuan prinsip syariah.

Adapun pasal 20 menjelaskan bahwa benda bergerak karena sifatnya yang dapat diwakafkan meliputi:

a. Kapal;

b. Pesawat terbang;

c. Kendaraan bermotor;

d. Mesin atau peralatan industri yang tidak tertancap pada bangunan, e. Logam dan batu mulia; dan/atau;

f. Bendalainnyayangtergolong sebagaibenda bergerak karena sifatnya dan memiliki manfaat jangka panjang.

Selanjutnya, pasal 21 menjabarkan bahwa benda bergerak selain uang karena peraturan perundang-undangan yang dapat diwakafkan sepanjang tidak bertentangan dengan prinsip syariah sebagai berikut:

a. Surat berharga berupa:

1. Saham;

2. surat utang Negara;

3. obligasi pada umumnya, dan/atau Surat berharga lainnya yang dapat dinilai dengan uang.

b. Hak atas kekayaan intelektual yang berupa:

1. Hak cipta;

2. Hak merk;

3. Hak paten;

4. Hak desain industry;

5. Hak rahasia dagang;

6. hak sirkuit terpadu;

7. Hakperlindungan varietas tanaman; dan/ atau

8. Hak lainnya.

c. Hak atas benda bergerak lainnya yang berupa:

1. Hak sewa, hak pakai dan hak pakai hasil atas benda bergerak; atau

2. Perikatan,tuntutanatasjumlahuangyang dapat ditagih atas benda bergerak.

\section{Pendayagunaan Uang Wakaf Yang Tidak Bertentangan Dengan Syariat Islam}

Pendayagunaan merupakan suatu upaya agar segala sesuatunya menjadi bermanfaat dan mendatangkan hasil. Dalam konteks wakaf uang ini, uang atau surat berharga lain yang diserahkan oleh wakif harus dikelola dan dimanfaatkan agar dapat menghasilkan sesuatu yang bermanfaat dan hasil tersebut dipergunakan sesuai dengan peruntukan atau ikrar yang dilakukan oleh wakif. Pasal 22 UU wakaf mengatur bahwa harta benda wakaf hanya boleh diperuntukan bagi: 
a. sarana dan kegiatan ibadah;

b. sarana dan kegiatan pendidikan serta kesehatan;

c. bantuan kepada fakir miskin, anak terlantar, yatim piatu, bea siswa;

d. kemajuan dan peningkatan ekonomi umat; dan/atau

e. kemajuan kesejahteraan umum lainnya yang tidak bertentangan dengan syariah dan peraturan perundang-undangan.

Wakaf dengan uang merupakan suatu terobosan sebagai upaya untuk memasyarakatkan wakaf itu sendiri. Dimana masyarakat tidak harus menunggu kaya agar dapat berwakaf, karena wakaf tidak ditentukan berapa nominal minimal yang harus diwakafkan. Menurut pasal 22 ayat (1 dan 2) PP 42 tahun 2006 bahwa wakaf uang yang dapat diwakafkan adalah mata uang rupiah; dalam hal uang yang akan diwakafkan masih dalam mata uang asing, maka harus dikonversi terlebih dahulu ke dalam rupiah.

Sardjon Permono sebagaimana dikutip oleh Jaih Mubarok, sesuatu dianggap uang apabila memiliki enam persyaratan utama: pertama, dapat diterima dan dapat diketahui secara umum sebagai alat tukar, penimbun kekayaan, dan standar pembayaran utang. Kedua, stabilitas nilai. Uang dapat diterima secara umum jika nilainya stabil atau jika terjadi fluktuasi naik-turunnya kecil. Ketiga, keseimbangan. Bank sentral sebagai pihak penerbit uang harus mampu membaca perkembangan perekonomian. Keempat, kemudahan. Uang mudah dibawa untuk dijadikan alat tukar dan standar pembayaran barang dan jasa. Kelima, terjaga fisiknya. Sedangkan keenam, pemantapan transaksi. Uang digunakan untuk memantapkan transaksi dalam berbagai jumlah. ${ }^{18}$

Menurut Hendra Kholid beberapa ulama berpendapat bahwa alasan boleh dan tidaknya mewakafkan mata uang berkisar pada apakah wujud uang tersebut setelah digunakan atau dibayarkan masih ada seperti semula atau tidak. Perdebatan ulama tentang unsure

${ }^{18}$ Jaih Mubarok.(2008). Wakaf Produktif. Bandung: Simbiosa Rekatama Media. "keabadian", pada dasarnya tidak lepas dari pemahaman mereka terhadap petunjuk Rasulullah kepada Umar ibn Khathab "Tahanlah pokoknya dan sedekahkan hasilnya". Menurut Abu Ishaq asy-Syirazi (w. $476 \mathrm{H} / 1083 \mathrm{M}$ ) petunjuk tersebut mengandung makna bahwa yang boleh diwakafkan adalah yang dapat bermanfaat dan tahan lama (tidak lenyap ketika dimanfaatkan $)^{19}$.

Nilai dasar dari hadist diatas adalah kontinuitas atas objek wakaf dan hasil yang diperoleh dari objek wakaf tersebut dapat memberikan manfaat dan kegunaan bagi kepentingan agama dan umat. Asas kemanfaatan benda wakaf menjadi landasan yang paling relevan dengan keberadaan benda itu sendiri. Lebih-lebih ibadah wakaf oleh para ulama dikatagorikan sebagai amal ibadah șhadaqah jariah yang memiliki nilai pahala yang terus mengalir walaupun yang melakukannnya telah meninggal dunia. Kontinyunitas pahala yang dimaksud itu karena terkait dengan aspek kemanfaatan yang bisa diambil secara berkesinambungan oleh pihak kebajikan (kepentingan masyarakat banyak $)^{20}$.

Ditinjau dari segi konsep mașlahah, bentuk wakaf uang mampu mendatangkan kemanfaatan yang sangat besar dalam segala aspek kehidupan. Wakaf uang menurut kaum sosialis matrealis mampu memenuhi segala keinginan rasio secara mutlak. Wakaf uang dinilai mampu memaksimalkan sumber dana wakaf. Wakaf uang juga dinilai mampu membukakan peluang bagi aset tetap untuk memasuki berbagai macam usaha investasi. Dari sinilah, wakaf uang dikatakan memiliki keluwesan dan tingkat kemaslahatan yang lebih tinggi dibanding dengan aset wakaf yang lainnya (aset tetap). ${ }^{21}$

Menurut Jaih Mubarok bentuk pengembangan wakaf uang disesuaikan dengan jenis uang itu sendiri. Ada dua jenis uang; pertama, dari segi bahan (material).

\footnotetext{
${ }^{19}$ Latif Ali Romadhoni, Op.Cit. hlm. 56

${ }^{20}$ Departemen Agama RI.(2005). Paradigma Baru Wakaf di Indonesia. Jakarta: Direktorat Pengembangan Zakat dan Wakaf. hlm. 72-73

${ }^{21}$ Latif Ali Romadhoni, Op. Cit.,. hlm. 61
} 
Dari segi ini, uang dibedakan menjadi dua, yaitu uang logam dan uang kertas. Bahan uang logam adalah emas, perak dan perunggu. Sedangkan bahan uang kertas adalah kertas itu sendiri. Uang kertas sendiri dibedakan menjadi dua, yaitu uang kartal, uang yang dikeluarkan oleh pemerintah atau bank sentral dan uang giral yaitu uang yang dikeluarkan oleh bank umum. Kedua, dari segi nilai. Dari segi ini uang juga dibedakan menjadi dua, yaitu uang yang bernilai penuh dan uang yang tidak bernilai penuh. Uang yang bernilai penuh adalah uang yang nilai kandungannya sama dengan nilai nominalnya. Sedangkan uang yang bernilai tidak penuh adalah uang nilai intrinsiknya lebih kecil dari nilai nominalnya. Uang yang tidak bernilai penuh tidak mempunyai nilai yang berarti sebagai barang non-moneter, tapi uang ini dalam peredaran mewakili sejumlah logam tertentu dengan nilai yang sama besarnya dengan nilai nominal uangnya ${ }^{22}$.

Apabila diperhatikan pemerintah sangat serius dalam mendayagunakan wakaf uang ini. Hal ini terlihat dari terperincinya peraturan perundang-undangan mengatur tentang wakaf uang ${ }^{23}$. Pengaturan tersebut bukan hanya menyangkut konsepsi terhadap wakaf dan wakaf uang tetapi juga menyangkut mekanisme administratifterhadap wakafuang. Pengaturan administratif tersebut bertujuan ditujukan untuk mengoptimalisasikan peran wakaf yang transparan, akuntabel dan produktif sehingga esensi wakaf itu sendiri dapat tercapai yakni untuk meningkatkan kesejahteraan bagi masyarakat.

Pendayagunaan harta benda (uang) wakaf dititikberatkan pada pemnfaatan secara ekonomi secara riil tanpa menghilangkan eksistensi dari harta benda wakaf itu sendiri sepanjang pengelolaan tersebut sesuai dengan prinsip manajemen dan ekonomi Syariah. Agar sejalan dengan nilai-nilai dasar ekonomi

${ }^{22}$ Abdurrahman Kasdi, (2014), Potensi Ekonomi dalam Pengelolaan Wakaf uang di indonesia, Jurnal equilibrium, Volume 2, No.1, hlm. 42

${ }^{23}$ Mulai dari UU No. 41 tahun 2004, PP No. 42 tahun 2006 diganti dengan PP No. 25 tahun 2008 dan Permenag No. 4 tahun 2009 syariah maka pendayagunaan wakaf uang dilakukan oleh Lembaga Keuangan Syariah (LKS) dalam hal ini oleh Perbankan Syariah (lihat pasal 28 UU Wakaf). Selanjutnya LKS akan menerbitkan Sertifikat Wakaf Uang sebagai bukti bahwa wakif telah mewakafkan sebagian dari hartanya. Kemudian LKS harus mendaftarkan harta benda wakaf berupa uang kepada menteri selambat-lambatnya 7 (tujuh) hari kerja sejak diterbitkannya Sertifikat Wakaf Uang.

Nazhir sebagai pihak yang ditugaskan untuk mengelola harta benda wakaf wajib melakukannya sesuai dengan ikrar wakaf yang dilakukan oleh wakif. Untuk melakukan pengelolaan tersebut nazhir dapat melakukan kerjasama dengan pihak lain asal tidak bertentangan dengan prinsip syariah (lihat pasal 45 ayat (1 dan 2) PP 42 tahun 2006). Pendayagunaan harta benda wakaf dengan melibatkan pihak lain dapat dilakukan melalui investasi pada produkproduk lembaga keuangan Syariah dan/atau instrument keuangan Syariah (pasal 48 ayat 2 PP 42 tahun 2006). Adapaun produk atau instrument syariah yang dapat digunakan untuk mendayagunakan harta benda wakaf misalnya adalah Mudharabah yakni akad kerjasama bagi hasil antara satu pihak dengan lain, dimana satu pihak menyediakan modal dan pihak lain mendayagunakan modal tersebut untuk usaha produktif dan keuntungan dari usaha tersebut dibagihasilkan antara kedua belah pihak.

Bentuk wakaf uang menurut Mundzir Qahaf terdiri dari tiga sejenis: pertama, badan wakaf bisa membolehkan dirinya menerima wakaf uang untuk mendanai proyek wakaf tertentu, seperti pabrik pembangunan perangkat komputer, kemudian memberikan hasilnya untuk tujuan wakaf tertentu, seperti untuk yayasan anak yatim piatu dan lain sebagainya. Dengan banyaknya hasil wakaf yang diperoleh, tujuan wakaf bisa banyak dan terdiri dari beberapa macam bentuk amal kebaikan. Badan wakaf juga bisa dari badan yang dibentuk oleh pemerintah atau menyerupai badan pemerintahan, 
sebagaimana juga bias dibentuk oleh pihak swasta. Para wakif bisa menyerahkan uangnya kepada badan wakaf untuk diinvestasikan dalam bentuk apapun yang dianggap layak dan sesuai, apabila badan wakaf memiliki banyak proyek wakaf produktif. ${ }^{24}$

Kedua, bentuk wakaf yang dilakukan dengan cara wakif menentukan dirinya sebagai pihak yang menginvestasikan uang. Maka wakaf uang diinvestasikan dalam bentuk wadi'ah (deposito) di bank Islam tertentu atau di unit-unit investasi lainnya. Dengan demikian, wakif menjadi nadzir atas wakafnya dengan tugas menginvestasikan wakaf uang dan mencari keuntungan dari wakafnya untuk dibagikan hasilnya kepada orang-orang yang berhak mendapatkannya. Sebagai nadzir, wakif juga bisa memindahkan investasi uang wakaf dari satu bank Islam ke bank Islam yang lain atau dari bentuk investasi wadi 'ah ke dalam bentuk investasi mudharabah, sebagaimana juga bisa memindahkannya ke lembaga investasi lain yang serupa. Akan tetapi perlu diingat, bahwa nadzir tidak bisa mengambil keputusan investasi uang wakaf dengan sendirinya, karena kewenangan dalam menginvestasikan uang wakaf terbatas kepada prosedur dan memilih pihak atau lembaga yang menginvestasikan wakaf uang tersebut ${ }^{25}$.

Ketiga, bentuk wakaf investasi yang banyak dilakukan orang saat ini dalam membangun proyek wakaf produktif, akan tetapi sebagian tidak ingin menyebutnya sebagai wakaf uang, karena harta telah beralih menjadi barang yang bisa diproduksi dan hasilnya diberikan untuk amal kebaikan umum. Bentuk yang sederhana dari sistem wakaf ini adalah dengan membentuk panitia pengumpul infak dan s \}adaqah untuk membangun wakaf sosial. Apabila kaum muslimin memerlukan masjid misalnya, biasanya dibentuk kepanitiaan untuk mengumpulkan dana dari para dermawan untuk membangun masjid. Namun pada kenyataannya, proyek-proyek wakaf seperti pembangunan masjid, rumah sakit,

\footnotetext{
${ }^{24}$ Abdurrahman Kasdi, Op.Cit., hlm. 42-43

${ }^{25}$ Ibid.
}

rumah anak yatim piatu dan lain sebagainya saat ini sangat banyak membutuhkan dana yang sangat jarang sekali dapat dipikul oleh satu orang saja, melainkan harus diselesaikan secara gotong royong. ${ }^{26}$

Akan tetapi alangkah lebih baik investasi yang dilakukan oleh LKS dari wakaf uang dilakukan pada usaha strategis yang langsung berhubungan dengan kebutuhan dan kesejahteraan masyarakat banyak yakni pada Sektor Kredit Mikro, Sektor Portofolio Keuangan Syari'ah, dan Sektor Investasi Langsung. Ketiga sektor tersebut sangat berdayaguna mendongkrak kegiatan ekonomi dan mendorong peningkatan kesejahteraan hidup masyarakat, dengan catatan bahwa seluruh kegiatan di sektor tersebut dikelola melalui manajemen yang profesional dan dukungan kebijakan politik dari pemerintah ${ }^{27}$.

Terlepas dari semua itu dalam mengelola dan mendayagunakan harta benda (uang) wakaf hendaknya memperhatikan keamanan atas uang tersebut. Keamanan investasi ini paling tidak mencakup dua aspek: pertama, keamanan nilai pokok dana abadi, sehingga tidak terjadi penyusutan (adanya jaminan keutuhan). Sedangkan kedua, investasi dana tersebut bisa diproduktifkan dan mampu mendatangkan hasil atau pendapatan (incoming generating allocation). Dari pendapatan inilah pembiayaan kegiatan lembaga akan dilakukan dan sekaligus menjadi sumber untuk pengembangan ekonomi umat. ${ }^{28}$ Untuk menjaga keamanan atas nilai uang wakaf tersebut maka pasal 48 ayat (4 dan 5) PP 42 tahun 2006 mengatur bahwa: Pengelolaan dan pengembangan atas harta benda wakaf uang yang dilakukan pada bank Syariah harus mengikuti program lembaga penjamin simpanan sesuai dengan peraturan perundang-undangan. Pengelolaan dan pengembangan atas harta benda wakaf uang yang dilakukan dalam bentuk investasi di luar bank Syariah harus diasuransikan pada asuransi Syariah.

\footnotetext{
${ }^{26}$ Ibid.

${ }^{27}$ Ibid., hlm. 45.

${ }^{28}$ Ibid.
} 


\section{KESIMPULAN}

Berdasarkan pada uraian hasil dan pembahasan diatas maka penulis menarik kesimpulan sebagai berikut: pertama, konsep wakaf merupakan konsep ijtihadiyah dikarenakan tidak ada ayat al-Qur'an maun Hadist yang mengaturnya secara eksplisit. Sehingga muncul banyak pendapat tentang kebolehan wakaf uang. Wakaf uang (cash waqf) bukan hal baru dalam dunia Islam, karena dalam beberapa mazhab klasik membolehkan wakaf uang misalnya dalam mazhab Hanbali dan sebagian ulama mazhab Syafi'I, sementara di Indonesia wakaf uang mulai dikenal dan mendapat legitimasi setelah adanya Fatwa MUI pada tanggal 11 Mei 2002: Kedua, wakaf uang telah mendapatkan legitimasi secara yuridis formal dalam system hukum Indonesia karena telah diatur dalam berbagai peraturan perundangundangan Indonesia, mulai dari UU No. 41 tahun 2004, PP No. 42 tahun 2006 diganti dengan PP No. 25 tahun 2008 dan Permenag No. 4 tahun 2009: ketiga, pendayagunaan harta benda (uang) wakaf dapat dilakukan oleh Lembaga Keuangan Syariah dalam hal ini oleh Perbankan Syariah menggunakan Instrumen-instrumen syariah, misalnya adalah adalah mudharabah dan musyarakah melalui pola bagi hasil dan keuntungan dari bagi hasil tersebut diperuntukan sesuai dengan ikrar wakaf yang dilakukan oleh wakif.

\section{DAFTAR PUSTAKA}

\section{Buku}

Abdul Ghofur Anshori.(2005). Hukum dan Praktek Perwakafan di Indonesia, Yogyakarta: Pilar Media.

Abdul Halim Barkatullah dan Teguh Prasetio,. (2006). Hukum Islam. Yogyakarta: Pustaka Pelajar.

Bank Indonesia.(2016). Wakaf: Pengaturan dan Tata Kelola yang Efektif,. Jakarta: Departemen Ekonomi dan Keuangan Syariah.
Departemen Agama RI.(2005). Paradigma Baru Wakaf di Indonesia. Jakarta: Direktorat Pengembangan Zakat dan Wakaf.

Kementerian Agama RI Direktorat Jenderal Bimbingan Masyarakat Islam Direktorat Pemberdayaan Wakaf. (2013). Buku Panduan Pengelolaan Wakaf Tunai.

Hamka.(1987).Tafsir Al-Azhar, Jakarta: Cet.1 Jilid IV,Pustaka Panjimas.

Jaih Mubarok.(2008). Wakaf Produktif, Bandung: Simbiosa Rekatama Media.

Muhammad Daud Ali.(1988). Sistem Ekonomi Islam, Zakat Dan Wakaf, Jakarta: Universitas Indonesia.

\section{Jurnal}

Aam S. Rusydiana\& Abrista Devi.(2017). Analisis Pengelolaan Dana Wakaf Uang Di Indonesia: Pendekatan Metode Analytic Network Process (Anp), Jurnal Al-Awqaf, Volume 10 No. 2.

Abdurrahman Kasdi.(2014). Potensi Ekonomi dalam Pengelolaan Wakaf uang di indonesia, Jurnal equilibrium, Volume 2, No.1.

Latif Ali Romadhoni.(2015). Studi Analisis Fatwa Majelis Ulama Indonesia Tahun 2002 Tentang Wakaf Uang, Jurnal Az Zarqa', Vol. 7, No. 1.

Miftahul Huda.(2012). Arah Pembaruan Hukum Wakaf Indonesia, Ulumuna Jurnal Studi Keislaman, Volume 16 Nomor 1.

Nawawi Thabrani.(2009). Wakaf Uang Dalam Perspektif Ushul Fiqh, Istinbath, IAIN Mataram, Volume 7 Nomor 2.

\section{Internet}

http://www.republika.co.id/berita/duniaislam/islam-nusantara/12/07/22/ m7jb3w-potensi-wakaf-uang- 
sungguh-luar-biasa.

http://wakafproduktif.org/hikmah-wakafsebagai-ibadah-sosial/. 